\title{
Altering the Geotechnical Properties of Clayey Soil by using Scrap Rubber
}

\author{
Md. Shah Azam 1 Anuj Kumar Sharma ${ }^{2}$, Anshi Agarwal ${ }^{3}$, Rachana Verma ${ }^{4}$ Laxmi Singh ${ }^{5}$, Nirala Jee \\ 1,4,5,6 B.tech student, Dept. of Civil Engineering Hi-Tech Institute of Engineering \& Technology, Ghaziabad, UP, India \\ ${ }^{2,3}$ Asst. Professor Dept. of Civil Engineering Hi-Tech Institute of Engineering \& Technology Ghaziabad, UP, India
}

\begin{abstract}
Altering the geotechnical properties by the addition of scrap rubber as a binding material in soil can be one of the method for soil stabilization. The production of scrap rubber tyres has been increased over the years in India. The scrap rubber material being left as a waste material can be later on used in soil so as to increase the properties of soil. Thus, it reduces the impact of rubber on environment. In current scenario the demand for infrastructures is increasing day by day. In some places the soil property is very loose and the foundation design is not suitable due to poor bearing capacity of soil. Hence we need to modify the property of soil. We are mixing the scrap rubber material in the powder form and chips form. These materials are mixed in different proportions and find the variation of these proportions in soil is identified. It is low cost method for altering the geotechnical properties of soil.
\end{abstract}

Key words - Clay soil, Waste crumb rubber tyre, unconfined compression test (UCS), standard proctor test (SPT).

\section{INTRODUCTION}

The production of scrap tyres has been increased over the years in India. The main objective is to increase the strength and to reduce the construction cost by using scrap rubber material. Scrap tyres can be used in several types either as powder or crumb or shredded or in chips form. The purpose of mixing the rubber material in soil mass is to improve its bearing capacity or stability and also reduce the settlement. The rubber tyre is a lightweight material. Since it is not easy to dispose the scrap rubber tyres, hence we can use it as a binding material for soil.

The generation of scrap tyres has been increased over the years in the world. The common practice used for disposal of the waste tyres such as stock piles, and fills and burning are considered as very dangerous to health of humans and ecological system. The main objective is to increase the strength and to reduce the construction cost by using scrap rubber material. The mixture of tyre shreds with in soil for highway bank construction can be a means of reusing tyres to handle economic and environmental applications, this also helps to solve geotechnical issues related to low shear strength of soil. This helps to solve the geotechnical properties of soil.

\section{Waste rubber tyre generation (global scenario)}

A steady stream of large volumes of waste rubber tyres is generated annually by the increase in the numbers of all types of vehicles. This is very fast. The annual increase in the number of tyres has become more severe in developed countries like UK, USA, INDIA, etc. due to expanding cities and ban on stockpiling and land filling of tyres in many countries. The waste rubber generation quantities of few developed and developing countries are listed in the following table.

Table -1 : Production of scrap rubber

\begin{tabular}{|l|l|c|l|}
\hline S. No. & Country & $\begin{array}{l}\text { Waste } \\
\text { Generation }\end{array}$ & Reference \\
\hline 1 & United Kingdom & 475 & 2006, Reschner Kurt \\
\hline 2 & USA & 290 & 2009, Fikselet.al \\
\hline 3 & Canada & 240 & 2005, Pehlken et.al \\
\hline 4 & France & 398 & 2006, ETRMA \\
\hline 5 & Germany & 585 & 2006, Reschner Kurt \\
\hline 6 & Italy & 380 & 2006, ETRMA \\
\hline 7 & Spain & 305 & 2006, Reschner Kurt \\
\hline 8 & China & 239 & 2006, Zhao Shulanet.al \\
\hline 9 & Sri Lanka & 190 & 2003, Mathews \\
\hline
\end{tabular}

Waste rubber tyre generation (Indian scenario)

India is one of the developing countries, In India there is a very fast annual increase in the number of vehicles leading to steady increase in the volume of consumption of waste rubber tyres day by day / year by year, it has been observed that the production of tyres and tube has been increased in every day/year. This following table are show annual consumption of waste tyre in India.

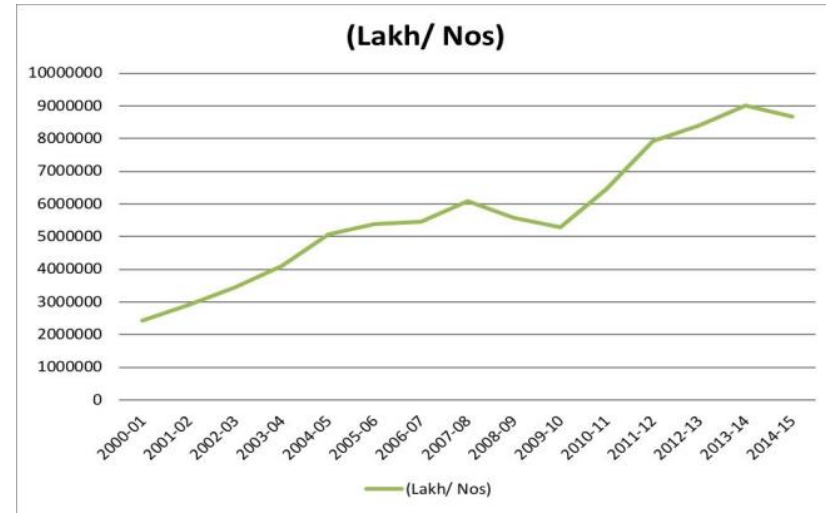


Table - 2: Chemical composition of waste tyres.

\begin{tabular}{|l|c|}
\hline \multicolumn{1}{|c|}{ Constituents } & Percentage \\
\hline Rubber (natural \& synthetic) & 38 \\
\hline Fillers (carbon chalk, carbon black, silica) & 30 \\
\hline Reinforcing materials (rayon, steel, nylon) & 16 \\
\hline Plasticizers (resins\& oil) & 10 \\
\hline $\begin{array}{l}\text { Chemical for vulcanization (zinc oxide, } \\
\text { sulphur) }\end{array}$ & 4 \\
\hline $\begin{array}{l}\text { Chemical as ntioxidants to counter ozone } \\
\text { effects }\end{array}$ & 1 \\
\hline \multicolumn{1}{|c|}{ Miscellaneous } & 1 \\
\hline
\end{tabular}

Table - 3: classification of waste tyre according to particle size.

\begin{tabular}{|c|c|}
\hline \multicolumn{2}{|c|}{ S1ze. } \\
\hline Material & Size \\
\hline Chips & $<250 \mathrm{~mm}$ \\
\hline Shred & $30-250 \mathrm{~mm}$ \\
\hline Granulate & $1-30 \mathrm{~mm}$ \\
\hline Powder & $<0.5 \mathrm{~mm}$ \\
\hline
\end{tabular}

\section{OBJECTIVE OF THE STUDY}

To alter the geotechnical properties of soil by using scrap tyres as a stabilizer.

$>\quad$ To determine the maximum dry density (MDD) \& optimum moisture content (OMC) for the various mixture.

$>\quad$ To find the optimum amount of crumb rubber tyre that can be added, such that changes in properties are in favor to our requirement.

$>\quad$ Study the engineering properties of rubber and soil.

$>$ To magnify the physical properties (Shear Strength, Water content, Compressibility) of the soil.

To determine the change in OMC, MDD \& shear strength with addition of different percentages of waste tyre rubber $(0 \%, 5 \%, 10 \%, 15 \%$ and $20 \%)$.

\section{SUMMARY OF LITERATURE REVIEW}

P. T. Ravichandran, A. Shiva Prasad, K. Divya Krishnan and P. R. Kannan Rajkumar Department of Civil Engineering, SRM University, Kattankulathur.

- Crumb rubber powder (CRP) mixed with both the soil showed improvement in CBR value with its addition up to $10 \%$ and there onwards decreased with further increase in crumb rubber powder.

- The permeability value shows rapid increase with the increase in crumb rubber content for the both the soils. The use of crumb rubber as a stabilizer introduces a low cost method for stabilization and it significantly reduces the waste tyre disposal problem that currently exits.

A. Venkata Ratnam, Dr. D. S. V. Prasad, Civil
Engineering Department, B.V.C. Engineering College, AP.

- From the Standard Proctor Compaction test, it was calculated that the maximum dry density (MDD) reduced with the increase in percentage of crumb rubber and optimum MDD is $1.48 \mathrm{KN} / \mathrm{m} 3$. This could be due to light weight nature of scrap crumb rubber waste.

- Cohesion(C) decrease with increase in CRP up to 7\% and then increases with further increase in $9 \%$ of CRP. Soil+CRP+cement mixture showed an improvement in direct shear value up to $9 \%$ of CRP at $4 \%$ cement. Further the addition of cement to soil +CRP mix lead to a decrease in direct shear value.

Umar jain, Vinod K Sonthwal, Department of civil engineering, NITTTR, Chandigarh, India.

- Added amount of rubber tyre had been varied in proportions of $4 \%, 6 \%, 8 \%$ and $10 \%$ by the weight of soil. Use of shredded rubber tyres in geotechnical engineering for enhancing the soil properties has received great attention in the current times.

- It is found that the $8 \%(25 \mathrm{~mm} \times 50 \mathrm{~mm})$ of tyre content is the specific value where the CBR has got the improvement of $66.28 \%$ than in comparison of the plain soil.

$>$ G. Ravi Kumar, K. Gayathri, Civil Engineering Department, QISIT, Ongole, AP, India.

- When the $10 \%$ of crumb rubber powder CRP are added in black cotton soil the shear strength of black cotton soil are increased. From the investigations, CBR value are increase in $10 \%$ of CRP are added to the soil.

- The addition of CRP in red soil when the shear strength of red soil are decreased. By the researcher investigation the use of rubber in red soil is not applicable for soil stabilization.

> Deepanshu Solanki, Dr. D.G.M Purohit, Department of Civil Engineering, M.B.M.E.C, J.N.V University, Jodhpur, Rajasthan, India.

- The shear strength is increased with the increasing the amount of scrap rubber up to 0.075 percentage by the weight.

- The smaller grain size provides greater contact area and better surface frictional resistance between chips and clay.

\section{RESEARCH METHODOLOGY}

\section{Preparation of Sample}

Specimens of parent soil and treated with $0,5,10,15$ and $20 \%$ by weight of rubber tyre scrap of various sizes were prepared at maximum dry density and optimum moisture content as per IS specification. 


\section{Testing}

Liquid Limit: - it is a minimum water content at which the soil is flow with minimum water content.

Apparatus: - kesagrande liquid limit test, kesagrande type tool (clay), ASTM type tool (sandy clay)

In this test we are taking $450 \mathrm{~mm}$ sieves and $120 \mathrm{gm}$ mixed water and massed it properly. And place the soil in to the cup now use the groove and tool which is divided the soil into two parts. Put the reading 0 . Now gives the no of blows we are providing 25 no .of blows until the soil is fixed gain its original position. When it is fixed we removed the soil from tool into the cup in perpendicular possition. And put it in to the container and weight the soil. Now put the sample in the Owen until the soil is dry. And again weighting the dry soil sample and noted the reading. We are repeating the test two or three times. And from all these values we are draw a graph in $\mathrm{x}$ - axis or $\mathrm{y}$ - axis

\section{Plastic limit test:-}

Plastic limit of a soil is a water content at which the soil just began to crumble when rod in to a threaded approximately $3 \mathrm{~mm}$.

Testing: - we are taking $50 \mathrm{gm}$. of soil sample and passing it from 425 micron sieve from the prepaid sample in the evaporating dish. Now add the still water in to the soil sample mixed it throwly.so that the soil mass is plastic enough to be used .prepaid the ball weight of $8 \mathrm{gm}$. out of this soil mass press the ball on the glass plate and rolled it with the fingers . So, that a threaded is uniform diameter is formed. The rate of rolling should be between 18-19 stokes per/minutes. Continue the rolling until the threading having a dia of $3 \mathrm{ml}$ and taking the reference to the metallic rod again make a ball of the thread and rolled it again to a threaded. We continue this process until the thread is crumbling .collect the sample of pieces of crumble soil thread in a container of non-weighting determine he moisture content as per standard procedure,

Water content $(\mathrm{w})=\mathrm{w} 1-\mathrm{w} 2 / \mathrm{w} 1-\mathrm{w} 2 * 100$

MDD Test (maximum dry density test), OMC (Optimum Moisture Content of Soil):-

To determine the relationship between water content and dry density of given soil and then to determine optimum moisture content and maximum dry density. This can be measured by mainly two methods standard Proctor Compaction Test and Modified Proctor. Both the test helps to determine the optimum moisture content that is required for a soil to attain maximum compaction

Optimum Moisture Content (OMC) This function of soil is tested through the site investigation process. The Optimum moisture content (OMC) or Optimum Water Content (OWC) is the moisture content at which the soil attains maximum dry density.

\section{Dry density of soil using core cutter test: -}

For this test we are calculating.

-Stability analysis.

-Bearing capacity.

-Degree of compaction.

\section{Mixing Proportion}

The scrap rubber tyre mixed in various proportions can be represented as in table number 4.

Table - 4: Various proportions of sample used.

\begin{tabular}{|c|c|c|}
\hline Sample & Soil (\%) & Scrap rubber tyre (\%) \\
\hline A & 100 & 0 \\
\hline B & 95 & 5 \\
\hline C & 90 & 10 \\
\hline D & 85 & 15 \\
\hline E & 80 & 20 \\
\hline
\end{tabular}

\section{EXPRIMENTAL OBSERVATION}

The soil specimen of the parent soil was taken. Soil specimen replaced with $0,5,10,15$ and $20 \%$ of scrap rubber tyre by the weight.

\begin{tabular}{|c|c|c|c|c|c|c|}
\hline Description of & Properties & \multicolumn{5}{|c|}{ Scrap rubber tyre percentage } \\
\cline { 2 - 7 } Sample & & $0 \%$ & $5 \%$ & $10 \%$ & $15 \%$ & $20 \%$ \\
\hline $\begin{array}{c}\text { Soil + Scrap rubber } \\
\text { tyre (retained on } \\
425 \mu)\end{array}$ & OMC in \% & 25 & 23.2 & 22.4 & 21.1 & 19.4 \\
\cline { 2 - 7 } & MDD in $\mathrm{gr} / \mathrm{cc}$ & 1.60 & 1.574 & 1.561 & 1.476 & 1.458 \\
\hline $\begin{array}{c}\text { Soil + Scrap rubber } \\
\text { tyre (retained on } \\
300 \mu \text { ) }\end{array}$ & OMC in \% & 24 & 23.3 & 22.9 & 21.0 & 20.7 \\
\cline { 2 - 7 } & MDD in gr/cc & 1.60 & 1.58 & 1.534 & 1.48 & 1.455 \\
\hline
\end{tabular}

Table - 5: Index properties of Sample.

\begin{tabular}{|l|c|l|}
\hline \multirow{2}{*}{ Physical Properties } & \multicolumn{2}{|l|}{ Sample } \\
\cline { 2 - 3 } & Result & Scrap rubber tyre \\
\hline Specific Gravity & 2.58 & $\begin{array}{l}\text { Passing from } 600 \mu \text { sieve } \\
\text { \& retained on } 425 \mu \text { sieve }\end{array}$ \\
\hline Plastic Limit & 42 & \\
\hline Liquid Limit & 24 & \\
\hline Plasticity Index & 16 & Passing from $425 \mu$ sieve \\
\hline Maximum Dry Density (MDD) & 1.59 & \& retained on $300 \mu$ sieve \\
\hline Optimum Moisture Content (OMC) & 25 & \\
\hline
\end{tabular}

\section{RESULTS}

\section{Liquid Limit Test}

The test was done on the clayey soil first. The process of testing was followed as discussed earlier. Put $250 \mathrm{gm}$ sample, passed $425 \mathrm{~mm}$ sieve, into dish. Add distilled water into the soil.

Place a portion of the paste in the cup of device. Trim it to a depth of $1 \mathrm{~cm}$.

Rotate the cup at two revolutions per second till length of about $13 \mathrm{~mm}$ by flow, and record the number of blows, $\mathrm{N}$.

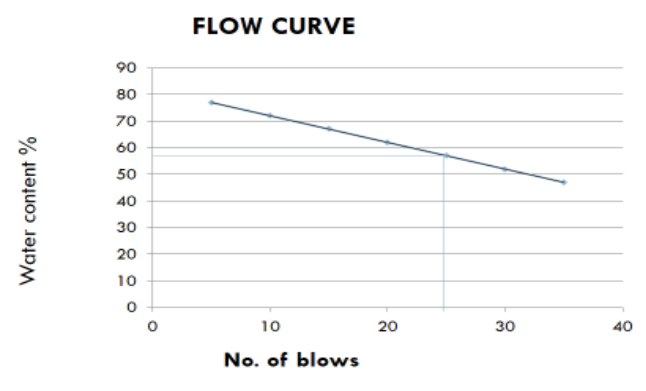

THE LIQUIDITY OF THE SOIL SAMPLE IS $57 \%$ 


\section{Standard Proctor Test}

Weight of empty mould $=4340 \mathrm{gm}$. Volume of empty mould $=1000 \mathrm{cc}$.

Results obtained are listed below in Table 6

Table 6: Standard Proctor Test Values for Different Percentage of CRP

\begin{tabular}{|l|l|l|l|l|l|}
\hline \%CRP & 0 & 5 & 10 & 15 & 20 \\
\hline MDD & 15.3 & 14.7 & 14.2 & 13.6 & 13.1 \\
\hline OMC & 25 & 23.2 & 21.9 & 18.8 & 17 \\
\hline
\end{tabular}

\section{Standard proctor test on soil}

The test was done on the clayey soil first. The Maximum Dry Density was found to be $1.72 \mathrm{~g} / \mathrm{cc}$ at Optimum Moisture Content of $20.8 \%$. The process of testing was followed as discussed earlier.

MAXIMUM DRY DENSITY \& OPTIMUM MOISTURE CONTENT

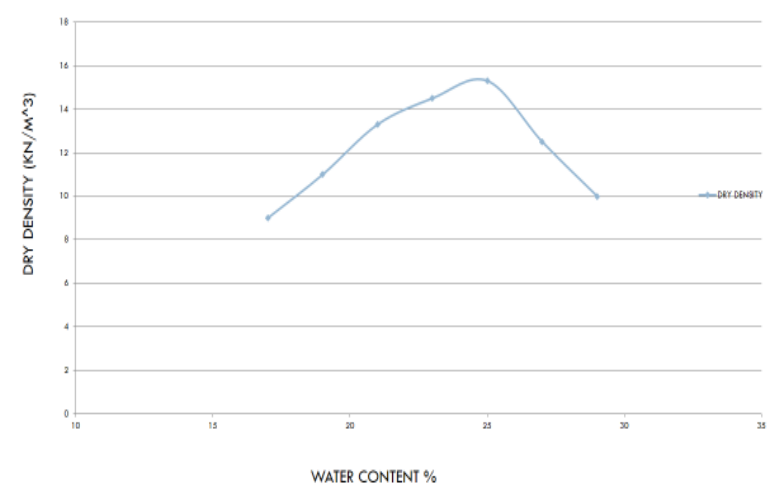

\section{Standard proctor test on blended soil}

The process described earlier was repeated for all the samples

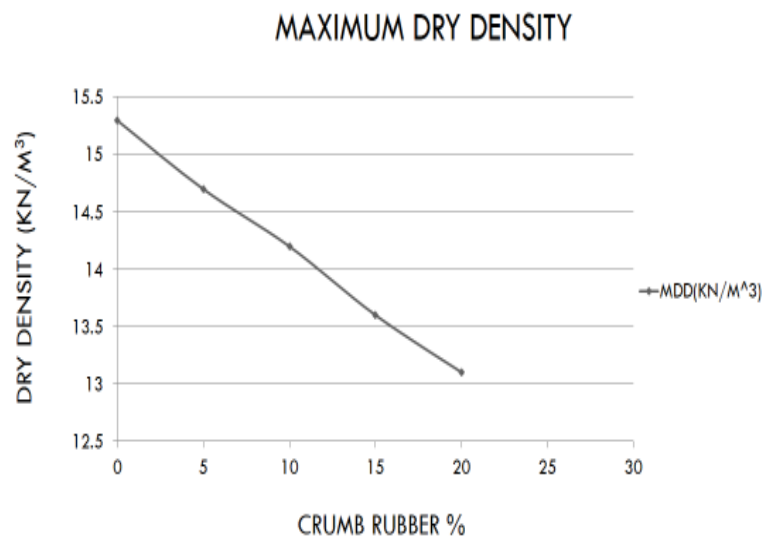

It can be observed that the increase in percentage of crumb rubber decreases the MDD

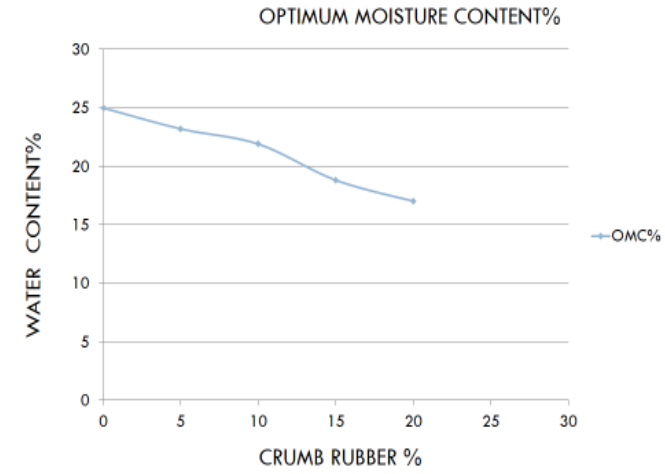

It can be observed that the increase in percentage of crumb rubber decreases the OMC

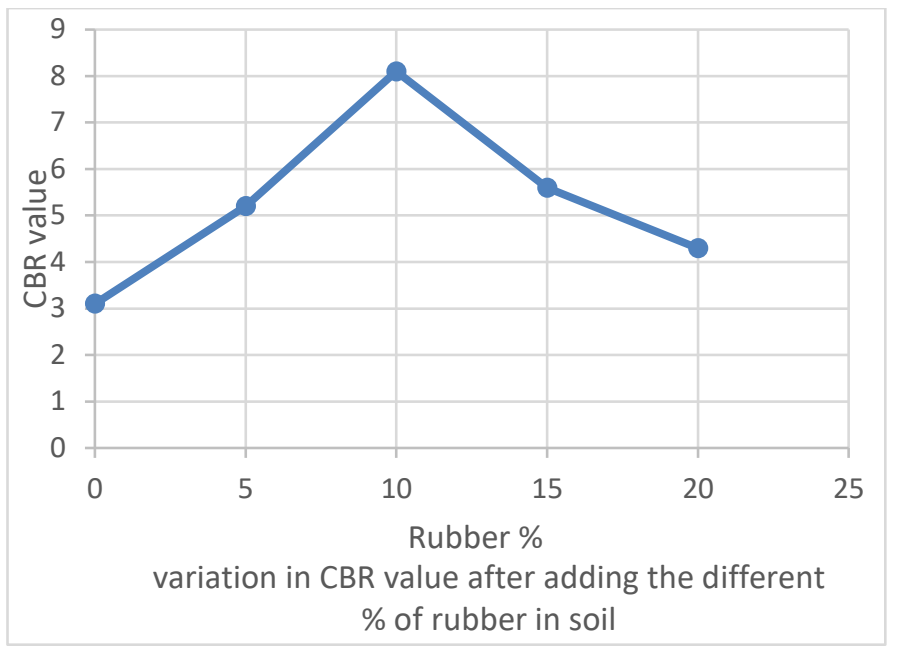

\section{CONCLUSION}

- After investigation of the test results are presented in table and figures of plotted graphs, following conclusion were drawn about the experimental study.

- The optimum moisture content (OMC) will be varies about $17 \%$ to $20 \%$ due to addition of scrap rubber tyre as form of shredded rubber content .The shear strength increased with the increasing amount of rubber up to 20 percentage by its weight.

- Strength was increased and thus it can be used for further constructions and in constructions of roads, bridge, and foundation work.

- The percentage reduction in liquid limit and plasticity index was about 50\% \& 54\% when 4\% CRP was added.

- Results of tests conclude that involvement of chips scrap (waste) rubber tyre strips in clay with proper amounts improved strength and shapeless behavior of sub grade soils. For scrap rubber tyre contemplated soil, the value of Unconfined Compressive Strength (UCS) is greater in compare to parent soil.

- For soil treated with $20 \%$ of scrap rubber tyre (Retained - $425 \mu$ - scrap rubber tyre passing through $600 \mu$ and retained on $425 \mu$ IS sieve), and the highest unconfined compressive strength (UCS) value of $68 \mathrm{KN} / \mathrm{m}^{2}$ has been observed.

- The scrap rubber tyre chips using to reduce the environmental impact of scrap rubber tyre waste. 


\section{R EFERENCES}

[1] Amin, E.R. (2012) "A Review on the Soil Stabilization Using Low-Cost Methods". Journal of Applied Sciences Research, pp.2193-2196.

[2] Bayka I, G., Yesiller, N. and Koprulu, K, (1992), "Rubber-Clay Liners against Petroleum Based Contaminants", Environmental Geotechnology, pp 477-481.

[3] Cabalar, A. F. Direct Shear Tests on Waste Tyres-Sand Mixtures. Geotechnical and Geological Engineering, Volume 29, Issue 4, 2011, pp. 411-418

[4] Umar Jan, Vinod K. Sonthwal, Ajay Kumar Duggal, Er. Jasvir S. Rattan, Mohd Irfan (2015), "Soil Stabilization Using Shredded Rubber Tyre "International Research Journal of Engineering and Technology (IRJET) e-ISSN: 2395-0056 Volume: 02, Issue: 09 Dec-2015, pp. 741-744.

[5] Swarna Surya Teja, Paleru Siddhartha(2015), Subgrade soil of Highway Pavement using Waste Tyre Pieces" International Journal of Innovative Research in Science, Engineering and Technology (An ISO 3297: 2007 Certified Organization), Vol. 4, Issue 5, May 2015, pp.3265-3273

[6] IS: 2720 (Part 10) (1991), "Indian Standard Methods of Test for Soils: Determination of Unconfined Compressive Strength", Bureau of Indian Standards.

[7] Singh, Alam and Chowdhary, G.R. (1994), "Soil Engineering in Theory and Practice", Geotechnical Testing and Instrumentation Vol. 23, CBS Publishers and Distributors, Delhi.

[8] Ajay, K., and Jawaid, S.M. (2013) "Soil Modification Using
Shredded Scrap Tyres". International Journal of Biological Sciences \& Technological Research (IJBSTR) Research Papers, Vol. 1, pp.10-13.

[9] Amin, E.R. (2012) "A Review on the Soil Stabilization Using Low-Cost Methods". Journal of Applied Sciences Research, pp.2193-2196.

[10] Prasad, D.S.V., Prasad Raju, G.V.R. and Anjan, M Kumar. (2009) "Utilization of Industrial Waste in Flexible Pavement Construction". Journal of Geotechnical Engineering, Vol. 13, pp.1-12.

[11] B. Sri Vasavi, Dr. D.S.V. Prasad, A.C.S.V. Prasad "Stabilization of soil using crumb rubber powder and cement International journal of innovative research and technology.

\section{AUTHOR PROFILE}

Md Shah Azam B.tech in Civil Engineering from $\mathrm{Hi}$-Tech Institute of Engineering \& Technology, Ghaziabad, Uttar Pradesh, (India) affiliated to Dr. A.P.J. Abdul Kalam Technical University, Lucknow, Uttar Pradesh (India). 